\title{
PRESENTACIÓN: HASTA LA PRÓXIMA ÚlTIMA DÉCADA
}

CON ESTA ENTREGA DE la Última Década, llegamos a su número 25 de publicación. Iniciada hace 14 años (1993) en la localidad de Las Achupallas, Viña del Mar, Chile; con esa memorable imagen angustiante de una pareja de jóvenes "gastando el tiempo» en alguna esquina de Las Achupallas, que presentábamos en su portada impresa del primer número (como podrán rememorar quienes han seguido de cerca la revista). Tan angustiante resultó — como efecto no esperado- aquella imagen, que decidimos nunca más incluir alguna fotografía en su portada, quedando su diseño sin alteraciones hasta el día de hoy.

Similar suerte corrió el nombre de la revista con el fin de la década, siglo y milenio pasado, que en sentido estricto se terminaba con esa Última Década que anunciábamos, y que quizás con su nombre —inconscientemente - no le dábamos mucho tiempo a este proyecto editorial de CIDPA; o también fruto de los tempos que se asocian a ciclos vitales en cuanto a las concepciones sobre qué temporalidades pueden ser concebidas como de corto, mediano y largo plazo. Sin duda que en aquella época éramos aún más «jóvenes e indocumentados》, con veinte y pocos años en nuestras vidas, y con un reloj bastante más acelerado, que con el tiempo y los años pasó a ser reemplazado por el calendario.

Los propósitos con que lanzamos el primer número de la revista Última Década, en lo general no ban variado mucho, pudiendo consignar sólo su precisión temática a medio andar (alrededor del año dos mil), donde la revista comenzó — casi de manera exclusiva - a dedicarse al estudio y análisis en materias de juventud, con una clara orientación en el contexto de la juventud chilena y latinoamericana, que la ba constitui- 
Presentación

do en una importante referencia dentro de las (pocas) publicaciones periódicas que se dedican a las temáticas de juventud. De igual modo, la difusión de sus contenidos publicados siempre (y cada vez más) se han orientado bajo la lógica de acceso libre (en su versión impresa como electrónica) y disponible de manera integra en medios electrónicos gratuitos, partiendo por el sitio de CIDPA e incluyendo en la actualidad otros más.

Ha sido un largo camino y esfuerzo por nuestra parte, que no bace sino que llenarnos de satisfacción el haber podido lograr su continuidady mejoría en el tiempo y pensar en los desafios que se nos imponen para el futuro.

Por las páginas de la revista han pasado y dejado sus contribuciones la mayoría de los investigadores y gestores en temas de juventud, no sólo de Chile, sino que también de la región, de alli que incluimos en esta edición un indice de autores/ as y artículos para el periodo 1993-2006.

En estos 25 números editados, se han publicado 255 artículos de 205 autores y autoras, en un total de 4.530 páginas, y teniendo un tiraje de 20.000 ejemplares impresos en todas sus ediciones. Número sin duda bajo comparado con los cientos de miles de accesos y consultas virtuales en los diferentes sitios web en que está disponible la revista. Sólo los últimos tres números incluidos en la biblioteca electrónica Scielo.cl contabiliza 34.058 consultas de artículos, teniendo un promedio de 18.000 accesos a artículos por cada número, luego de un año de su publicación.

Todos estos antecedentes y los gratos recuerdos que nos provocan los orígenes de la revista, no hace más que redoblar las motivaciones y ganas de continuar con este lindo y fructifero proyecto editorial, de difusión y reflexión, en el que todos/as los/as compañeros/as de CIDPA, siempre hemos comprometido nuestros mejores esfuerzos, y esperamos seguir haciéndolo de la misma manera que hasta ahora, hasta la próxima y Ú1tima Década que se avecina.

OSCAR DÁVILA LEÓN

VALPARAÍSO (CHILE), DICIEMBRE 2006 